\title{
Arsenic and Uranium in Private Wells in Connecticut, 2013-15
}

\section{Major Findings}

- Nearly 1 out of 15 (7 percent) water samples from 674 private wells tested in Connecticut contained either arsenic or uranium at concentrations that exceed the U.S. Environmental Protection Agency's (EPA) maximum contaminant levels (MCLs) enforceable for drinking-water supplies of 10 micrograms per liter $(\mu \mathrm{g} / \mathrm{L})$ for arsenic or $30 \mu \mathrm{g} / \mathrm{L}$ for uranium.

- Of the 81 geologic units studied, 19 had at least one sample with arsenic or uranium concentrations that exceeded the MCL.

\section{Introduction}

The occurrence of arsenic and uranium in groundwater at concentrations that exceed drinking-water standards is a concern because of the potential adverse effects on human health. Some early studies of arsenic occurrence in groundwater considered anthropogenic causes, but more recent studies have focused on sources of naturally occurring arsenic to groundwater, such as minerals within aquifer materials that are in contact with groundwater. Arsenic and uranium in groundwater in New England have been shown to have a strong association to the geologic setting (Ayotte and others, 2003, 2006) and nearby streambed sediment concentrations (Robinson and Ayotte, 2006). In New Hampshire and Massachusetts, arsenic and uranium concentrations greater than human-health benchmarks have shown distinct spatial patterns when related to the bedrock units mapped at the local scale (Montgomery and others, 2003; Colman, 2011; Flanagan and others, 2014).

The Connecticut Department of Public Health (DPH; 2016) reported that there are about 322,600 private wells in Connecticut serving approximately 823,000 people, or 23 percent of the State's population. The State does not require that existing private wells be routinely tested for arsenic, uranium, or other contaminants; consequently, private wells are only sampled at the well owner's discretion or when they are newly constructed. The U.S. Geological Survey (USGS), in cooperation with the DPH, completed an assessment in 2016 on the distribution of concentrations of arsenic and uranium in groundwater from bedrock in Connecticut (fig. 1). This report presents the major findings for arsenic and uranium concentrations from water samples collected from 2013 to 2015 from private wells.

\section{Sources of Data on Arsenic and Uranium Concentrations}

The main objective of this study was to compile and analyze arsenic and uranium concentrations from private wells throughout Connecticut (fig. 1). In cooperation with the DPH, local health departments and districts used volunteers to visit randomly selected houses in their districts and collect an unfiltered water sample from an untreated source in the home. Staff from DPH also distributed bottles to homeowners at four agricultural fairs in Bethlehem, Durham, Goshen, and Woodstock; at water fair events in East Hampton and Colchester; and one home show in Hartford. These homeowners were instructed to collect an unfiltered water sample prior to any existing treatment system. The water samples, collected from 2013 to 2015, were submitted to the DPH Laboratory in Hartford for trace-element analysis according to EPA method 200.8 (U.S. Environmental Protection Agency, 1994).

The towns of Stamford, Weston, and Wilton have substantially more water samples and wells than the other studied towns. On average, 7 wells were sampled in most towns, whereas, 81 wells were sampled in Wilton; 110 wells, in Weston; and 732 wells, in Stamford, resulting in an unbalanced distribution of water samples in the State. To balance the distribution for the purposes of this study, 7 to 14 wells from Stamford, Weston, and Wilton were randomly selected for inclusion in the statewide dataset. This subset of samples represented less than 5 percent of the final statewide dataset, which consisted of 660 arsenic samples and 589 uranium samples collected from 674 wells. Data for these 674 wells are available in Flanagan and Brown (2017). All available data from these three towns are discussed in the "Comparison of Arsenic and Uranium Exceedance Rates in Three Towns" section.

As part of the quality assurance plan for this study, the USGS submitted six standard reference samples to the DPH Laboratory with concentrations of arsenic and uranium spanning the range of expected environmental values. These samples were supplied by the USGS Branch of Quality Systems (U.S. Geological Survey, 2016) in Denver, Colo., and provided an independent analysis of measurable bias. Results from the analysis of the standard reference samples (table 1) indicated no measurable bias. 


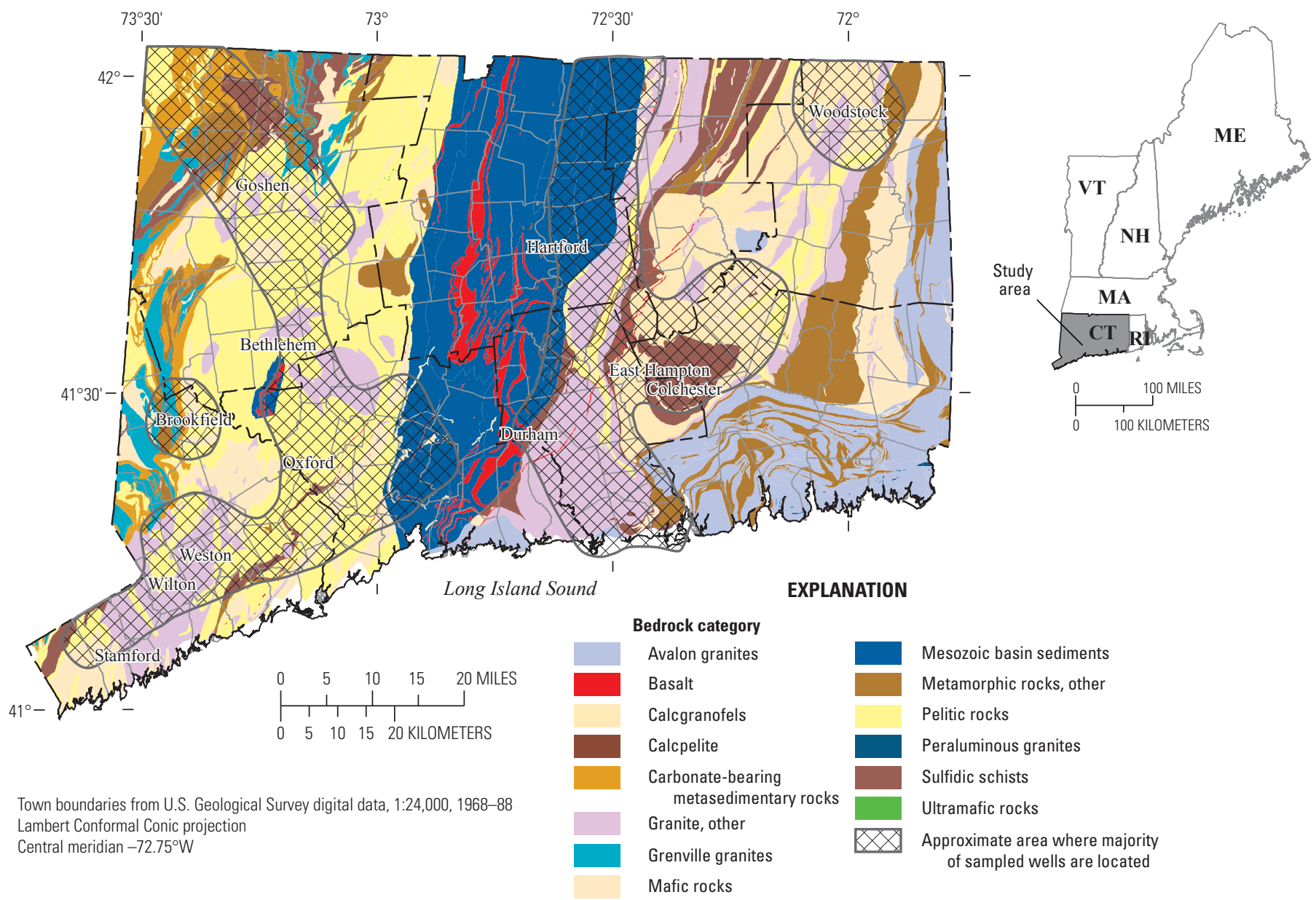

Figure 1. Locations of major categories of bedrock in Connecticut and areas where the majority of sampled wells are located. Modified bedrock categories are described in Robinson and Kapo (2003).

Table 1. Inventory of standard reference samples for arsenic and uranium concentrations, in 2015.

[SRS, standard reference sample; \#, number; $\mu \mathrm{g} / \mathrm{L}$, microgram per liter; MPV, most probable value; DPH, Connecticut Department of Public Health Laboratory in Hartford, Conn.; <, less than; na, not applicable]

\begin{tabular}{|c|c|c|c|c|c|c|c|}
\hline \multirow[t]{2}{*}{ SRS lot\# } & \multirow[t]{2}{*}{$\begin{array}{l}\text { Submission } \\
\text { Date }\end{array}$} & \multicolumn{3}{|c|}{$\begin{array}{c}\text { Arsenic } \\
\text { concentration, } \\
\text { in } \mu \mathrm{g} / \mathrm{L}\end{array}$} & \multicolumn{3}{|c|}{$\begin{array}{c}\text { Uranium } \\
\text { concentration, } \\
\text { in } \mu \mathrm{g} / \mathrm{L}\end{array}$} \\
\hline & & MPV & DPH & RPD $^{1}$ & MPV & DPH & RPD' \\
\hline $\mathrm{T}-219$ & $6 / 30 / 2015$ & 3.51 & $<3.00$ & na & 1.58 & 1.50 & 5.2 \\
\hline $\mathrm{T}-201$ & $7 / 28 / 2015$ & 24.4 & 23.0 & 5.9 & 9.22 & 9.20 & 0.2 \\
\hline $\mathrm{T}-201 \mathrm{~b}$ & $8 / 18 / 2015$ & 24.4 & 23.0 & 5.9 & 9.22 & 9.10 & 1.3 \\
\hline $\mathrm{T}-217 \mathrm{~A}$ & $8 / 31 / 2015$ & 5.99 & 5.80 & 3.2 & 1.78 & 1.70 & 4.6 \\
\hline $\mathrm{T}-217 \mathrm{~B}$ & 9/29/2015 & 5.99 & 5.20 & 14.1 & 1.78 & 1.70 & 4.6 \\
\hline $\mathrm{T}-201 \mathrm{c}$ & $9 / 29 / 2015$ & 24.4 & 22.0 & 10.3 & 9.22 & 9.30 & 0.8 \\
\hline
\end{tabular}

${ }^{1}$ Relative percent difference $=[\mid($ Sample $1-$ Sample 2) $\mid /$ Average (Sample $1+$ Sample 2)] $\times 100$, where sample 1 is the MPV value and sample 2 is the DPH value.

\section{Arsenic and Uranium Concentrations in the State}

Arsenic concentrations ranged mostly (95th percentile) from less than $(<) 3$ to 7.1 micrograms per liter $(\mu \mathrm{g} / \mathrm{L})$. Uranium concentrations ranged mostly (95th percentile) from $<1$ to $23 \mu \mathrm{g} / \mathrm{L}$ (table 2). Arsenic at concentrations at or above the minimum reporting level (MRL) of $3 \mu \mathrm{g} / \mathrm{L}$ was measured in 9.1 percent of samples. Uranium at concentrations at or above the MRL of $1 \mu \mathrm{g} / \mathrm{L}$ was measured in 42.1 percent of the samples. Statewide, 3.6 percent of samples had arsenic concentrations that exceeded the MCL of $10 \mu \mathrm{g} / \mathrm{L}$, and 3.9 percent had uranium concentrations that exceeded the MCL of $30 \mu \mathrm{g} / \mathrm{L}$ (table 2). Overall, about 7 percent of the samples had concentrations of arsenic or uranium that exceeded an MCL.

\section{Arsenic and Uranium Occurrence in Relation to Bedrock Geology}

There are distinct areas in Connecticut where one or more groundwater samples have arsenic and uranium concentrations greater than their respective MCLs (fig. 2). Data were grouped in relation to mapped bedrock units (referred to as geologic units in this report) identified on the bedrock geological map of Connecticut (Rodgers, 1985). It was assumed that each well was drilled and completed in the geologic unit represented at the 
Table 2. Arsenic and uranium concentrations in water samples from 674 private wells in Connecticut, 2013-15.

[No., number; MRL, minimum reporting level; $\mu \mathrm{g} / \mathrm{L}$, microgram per liter; MCL, U.S. Environmental Protection Agency maximum contaminant level for public water supplies; Min, minimum; Max, maximum; <, less than]

\begin{tabular}{|c|c|c|c|c|c|c|c|c|c|c|c|}
\hline \multirow{3}{*}{$\begin{array}{c}\text { Trace } \\
\text { element }\end{array}$} & \multirow{3}{*}{$\begin{array}{c}\text { No. of } \\
\text { samples }\end{array}$} & \multirow{3}{*}{$\begin{array}{c}\text { MRL, } \\
\text { in } \mu \mathrm{g} / \mathrm{L}\end{array}$} & \multirow{3}{*}{$\begin{array}{l}\text { Percentage of } \\
\text { samples with } \\
\text { concentrations } \\
\text { equal to or } \\
\text { exceeding MRL }\end{array}$} & \multicolumn{6}{|c|}{ Concentration, in $\mu \mathrm{g} / \mathrm{L}$} & \multirow{3}{*}{$\begin{array}{c}M C L, \\
\text { in } \mu \mathrm{g} / \mathrm{L}\end{array}$} & \multirow{3}{*}{$\begin{array}{l}\text { Percentage of } \\
\text { samples with } \\
\text { concentrations } \\
\text { exceeding MCL }\end{array}$} \\
\hline & & & & \multirow{2}{*}{ Min. } & \multicolumn{4}{|c|}{ Percentile } & \multirow{2}{*}{ Max. } & & \\
\hline & & & & & 50 & 75 & 90 & 95 & & & \\
\hline Arsenic & 660 & 3 & 9.1 & $<3$ & $<3$ & $<3$ & $<3$ & 7.1 & 470 & 10 & 3.6 \\
\hline Uranium & 589 & 1 & 42.1 & $<1$ & $<1$ & 3.2 & 9.3 & 23 & 766 & 30 & 3.9 \\
\hline
\end{tabular}

well's location on the geologic map. Geologic units are rocks of a specific geologic age that have unique mineral and physical characteristics, varying degrees of resistance to weathering, and similar processes of rock formation. Arsenic and uranium samples were grouped according to the geologic units in which the sampled wells are located (table 3).

Of the 156 geologic units in the State, 81 units (covering 82.6 percent of the land area), were represented by at least one water sample analyzed for arsenic and (or) uranium (table 3 ). Twenty-one geologic units had only 1 sample, 43 geologic units had 2 to 10 samples, and 17 geologic units had more than 10 samples. The 81 geologic units were organized under 10 different bedrock categories and are listed in table 3. These bedrock categories (fig. 1) are based on groups of individual geologic units with similar geochemical and lithological properties (Robinson and Kapo, 2003). The percentage of samples in each geologic unit with arsenic and uranium concentrations that exceeded MCLs was computed and then geologic units were grouped and colored based on percentage ranges (fig. 2). The exceedance percentages for geologic units computed for this study may not represent the actual hazard for existing and future wells in these units. Nonetheless, this report provides new information on arsenic and uranium contamination at the State scale.

Results of this analysis indicate that the geologic units were markedly different in terms of arsenic and uranium concentrations that exceeded MCLs (table 3). Nine of 81 geologic units had at least one sample with arsenic concentrations that exceeded the MCL of $10 \mu \mathrm{g} / \mathrm{L}$. Fourteen geologic units had at least one sample with uranium concentrations that exceeded the MCL of $30 \mu \mathrm{g} / \mathrm{L}$. None of the geologic units in the carbonatebearing metasedimentary rocks, Grenville granites, mafic rocks, or metamorphic rocks, other bedrock categories had arsenic concentrations that exceeded the MCL (table 3). None of the geologic units in the Avalon granites, carbonate-bearing metasedimentary rocks, Grenville granites, Mesozoic basin sediments, or sulfidic schists bedrock categories had uranium concentrations that exceeded the MCL. The pelitic rocks bedrock category had three geologic units with at least one arsenic concentration that exceeded the MCL, and the granite, other bedrock category had seven geologic units with at least one uranium concentration that exceeded the MCL - the most among the 10 bedrock categories.

In the greater than (>) 20 to 30 percent group (table 3), the Taine Mountain and Collinsville Formation undivided (4 samples) and the Glastonbury Gneiss (20 samples) were the only geologic units with arsenic and (or) uranium concentrations that exceeded MCLs. In the $>30$ percent group, the Carringtons Pond Member of the Trap Falls Formation (3 samples) was the only geologic unit with concentrations that exceeded the MCL for arsenic, and the Dalton Formation and the Harrison Gneiss (3 samples each) were the only geologic units with concentrations that exceeded the MCL for uranium (table 3).

The well with the highest arsenic concentration $(470 \mu \mathrm{g} / \mathrm{L})$, from the town of Oxford, is completed in The Straits Schist geologic unit of the Pelitic rocks bedrock category. Although 8.3 percent of the 12 samples in this geologic unit also have high arsenic $(>10 \mu \mathrm{g} / \mathrm{L})$, six other geologic units (table 3$)$ in the State have higher percentages of samples with high arsenic. This finding shows that wells with elevated arsenic are not always in the most high-risk areas.

The well with the highest uranium concentration (766 $\mu \mathrm{g} / \mathrm{L})$, from the town of Brookfield, is completed in the Dalton Formation geologic unit of the Metamorphic rock, other bedrock category. In a neurotoxicity case study in Brookfield, it was determined that a family was unknowingly exposed to well water containing 866 to $1,166 \mu \mathrm{g} / \mathrm{L}$ of uranium (Magdo and others, 2007). The private well in the case study was located in the Brookfield Gneiss geologic unit, a mafic rock common throughout the Appalachian ridges of western Connecticut. Magdo and others (2007) sampled 10 other wells in close proximity to the case-study well and discovered widely variable uranium concentrations ranging from 0.21 to $521 \mu \mathrm{g} / \mathrm{L}$. Altogether, 4 of the 11 wells in Magdo and others (2007) exceeded the MCL for uranium. However, none of the 12 water samples from the Brookfield Gneiss geologic unit of the Mafic rocks bedrock category in this study exceeded the MCL for uranium (table 3). This finding shows that uranium concentrations can be highly variable, even in wells in close proximity to each other or in similar geologic settings. These two examples for wells with elevated arsenic and uranium concentrations highlight the importance of individual well testing for naturally occurring contaminants.

\section{Comparison of Arsenic and Uranium Exceedance Rates in Three Towns}

A select group of geologic units have concentrations of arsenic and (or) uranium that exceed MCLs (fig. 2; table 3). Therefore, a town's vulnerability to arsenic and uranium contamination may depend greatly on the extent 


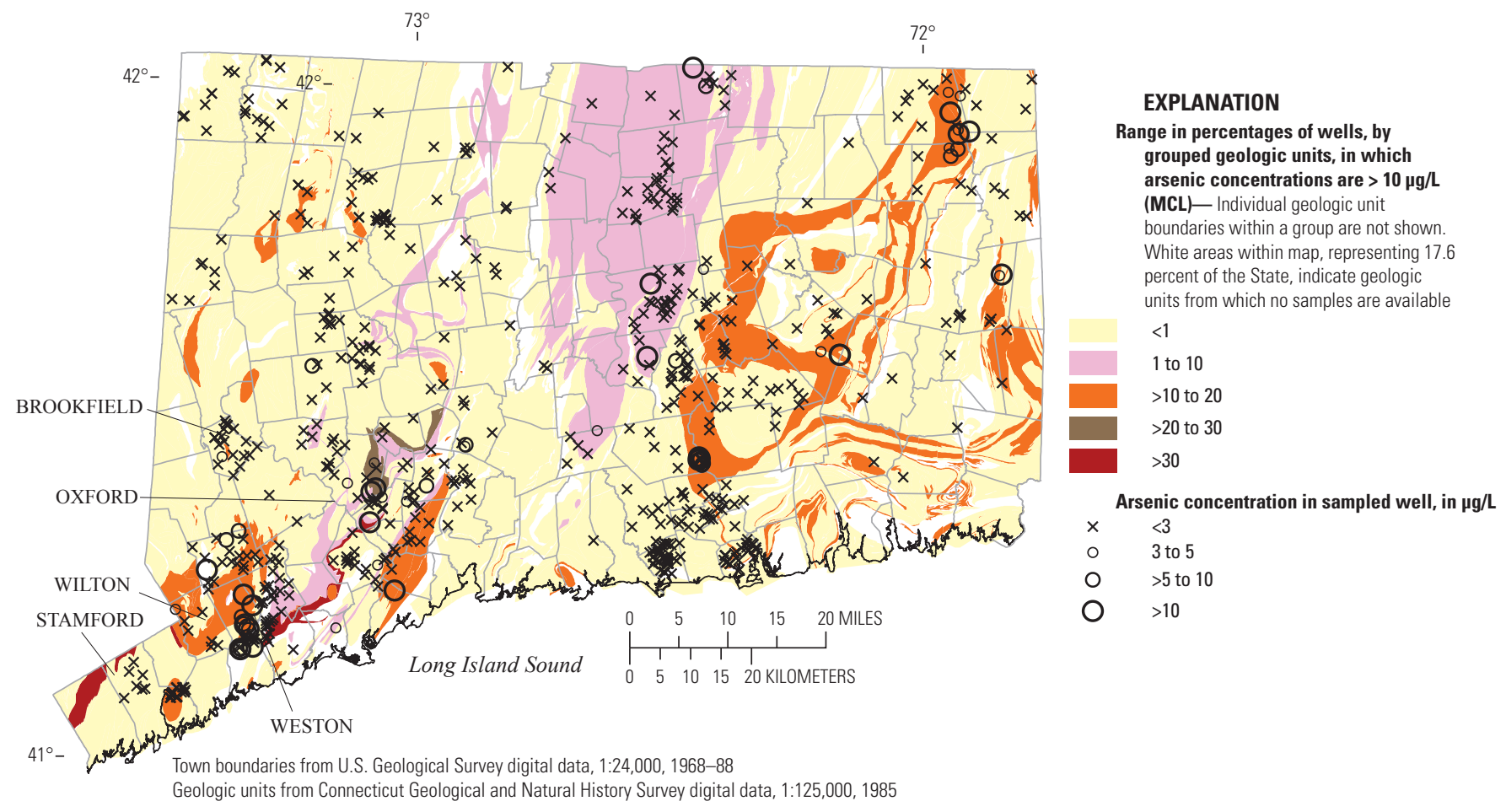

B. Percentage of wells, by grouped geologic units with uranium concentrations $>30 \mu \mathrm{g} / \mathrm{L}$ (MCL)

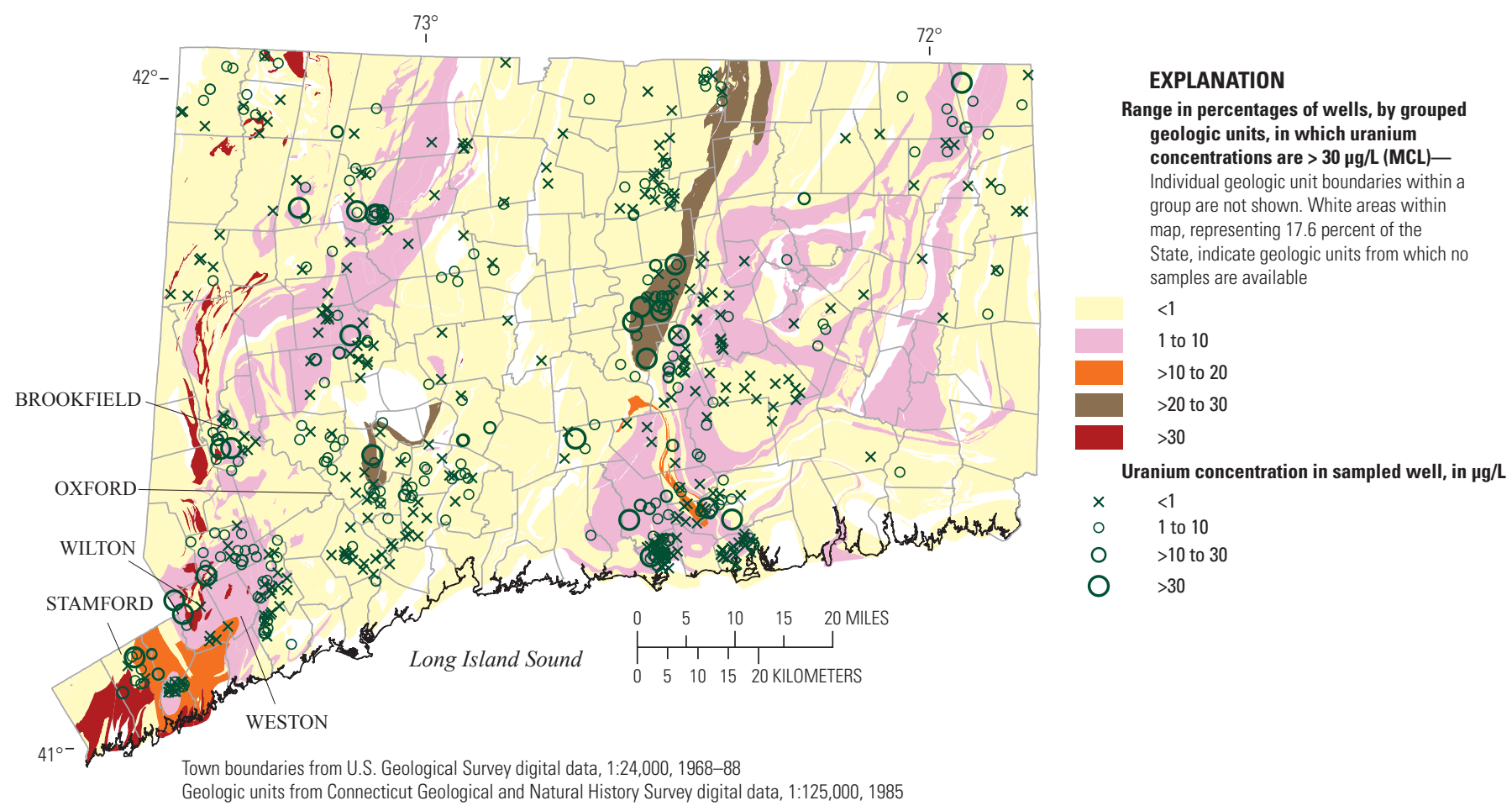

Figure 2. Range of percentages of private wells in Connecticut, by grouped geologic units, in which $A$, arsenic concentrations exceeded the maximum concentration level (MCL) of 10 micrograms per liter $(\mu \mathrm{g} / \mathrm{L})$ and $B$, uranium concentrations exceeded the $\mathrm{MCL}$ of $30 \mu \mathrm{g} / \mathrm{L}$. Concentrations of arsenic and uranium in water samples collected from 674 individual wells and the spatial distribution of the wells are also shown. Well locations have been offset by one-fourth mile to maintain the confidentiality of the well owner's identity. Geologic units are listed in table 3 . See Rodgers (1985) for the location and description of individual geologic units. <, less than; > greater than. 
Table 3. Arsenic and uranium concentrations that exceed maximum contaminant levels from 674 private wells in Connecticut, by geologic unit and major bedrock category, 2013-15.

[Geologic unit names are the Connecticut Department of Energy and Environmental Protection preferred names as modified from Rodgers (1985). Bedrock categories (subheadings) are modified from Robinson and Kapo (2003). Color shadings indicate the percentage of wells with exceedances above concentration thresholds in ranges of , no data $(-)$; , less than $(<) 1$ percent;, 1 to 10 percent; $\square$, more than $(>) 10$ to 20 percent; $\square,>20$ to 30 percent; and $\square,>30$ percent. MCL, U.S. Environmental Protection Agency maximum contaminant level enforceable for public water supplies; $\mu \mathrm{g} / \mathrm{L}$, microgram per liter; NA, not available]

\begin{tabular}{|c|c|c|c|c|c|c|}
\hline \multirow[t]{2}{*}{ Geologic unit name } & \multirow[t]{2}{*}{$\begin{array}{l}\text { Geologic } \\
\text { unit code }\end{array}$} & \multicolumn{2}{|c|}{ Number of samples } & \multicolumn{2}{|c|}{$\begin{array}{l}\text { MCL, percentage }{ }^{1} \text { of } \\
\text { water samples with } \\
\text { concentrations, in } \\
\text { micrograms per liter }\end{array}$} & \multirow{2}{*}{$\begin{array}{c}\text { Percentage } \\
\text { of study area } \\
\text { underlain } \\
\text { by geologic } \\
\text { unit }^{2}\end{array}$} \\
\hline & & Arsenic & Uranium & $\begin{array}{l}\text { Arsenic } \\
>10 \mu \mathrm{g} / \mathrm{L}\end{array}$ & $\begin{array}{l}\text { Uranium } \\
>30 \mu \mathrm{g} / \mathrm{L}\end{array}$ & \\
\hline \multicolumn{7}{|c|}{ Avalon granite } \\
\hline "Scituate" Granite Gneiss & Zss & 1 & 1 & 0 & 0 & 0.7 \\
\hline Hope Valley Alaskite Gneiss & Zsh & 5 & 3 & 20.0 & 0 & 2.1 \\
\hline Plainfield Formation & $\mathrm{Zp}$ & 3 & 2 & 0 & 0 & 1.4 \\
\hline porphyritic phase of Potter Hill Granite Gneiss & Zspp & 1 & 1 & 0 & 0 & $<0.2$ \\
\hline Potter Hill Granite Gneiss & Zsph & 2 & 2 & 0 & 0 & 1.3 \\
\hline $\begin{array}{l}\text { Potter Hill Granite Gneiss and Narragansett Pier Granite undi- } \\
\text { vided }\end{array}$ & $\mathrm{Zsph}+\mathrm{Pn}$ & 1 & 1 & 0 & 0 & $<0.2$ \\
\hline Rope Ferry Gneiss of the "Waterford Group" & Zwr & 5 & 5 & 0 & 0 & 1.1 \\
\hline \multicolumn{7}{|c|}{ Calcgranofels } \\
\hline Fly Pond (calc-silicate) member of Tatnic Hill Formation & Otaf & 1 & - & 0 & - & 0.4 \\
\hline Hebron Gneiss & SOh & 45 & 24 & 17.8 & 4.2 & 4.7 \\
\hline lower member of Bigelow Brook Formation & SObl & 2 & 2 & 0 & 0 & 0.6 \\
\hline Southbridge Formation & SOs & 5 & 2 & 0 & 0 & 1.0 \\
\hline
\end{tabular}

\begin{tabular}{|c|c|c|c|c|c|c|}
\hline \multicolumn{7}{|c|}{ Carbonate-bearing metasedimentary rocks } \\
\hline basal marble member of Walloomsac Schist & Owm & 4 & 4 & 0 & 0 & 0.5 \\
\hline Stockbridge Marble & OCs & 3 & 2 & 0 & 0 & 0.8 \\
\hline unit b of Stockbridge Marble & $\mathrm{Csb}$ & 6 & 6 & 0 & 0 & 0.4 \\
\hline unit c of Stockbridge Marble & Csc & 3 & 3 & 0 & 0 & 0.5 \\
\hline units e and d of Stockbridge Marble & Ose & 1 & 1 & 0 & 0 & $<0.2$ \\
\hline \multicolumn{7}{|c|}{ Granite, other } \\
\hline "Eastford gneiss phase" of Canterbury Gneiss & Dce & 2 & 1 & 0 & 0 & 0.5 \\
\hline Canterbury Gneiss & Dc & 2 & 1 & 0 & 0 & 1.2 \\
\hline Glastonbury Gneiss & Ogl & 22 & 20 & 4.5 & 25.0 & 1.7 \\
\hline lower member of Middletown Formation & Oml & 3 & 3 & 0 & 0 & $<0.2$ \\
\hline Middletown Formation & Om & 10 & 11 & 0 & 0 & 1.0 \\
\hline Monson Gneiss & Omo & 47 & 45 & 0 & 4.4 & 2.4 \\
\hline Nonewaug Granite & Dng & 10 & 10 & 0 & 10.0 & 0.6 \\
\hline Ordovician granitic gneiss & $\mathrm{Og}$ & 56 & 41 & 14.3 & 9.8 & 2.1 \\
\hline Trap Falls Formation and Ordovician granitic gneiss undivided & $\mathrm{Otf}+\mathrm{Og}$ & 3 & 9 & 0 & 11.1 & 1.0 \\
\hline upper member of Middletown Formation & Omu & 9 & 9 & 0 & 11.1 & 0.2 \\
\hline Waterbury Gneiss & $\mathrm{Cwb}$ & 1 & - & 0 & - & 0.8 \\
\hline Waterford Group & $\mathrm{Zw}$ & 26 & 25 & 0 & 4.0 & 0.8 \\
\hline \multicolumn{7}{|c|}{ Grenville granite } \\
\hline Gneiss of Highlands massifs & Yg & 4 & 4 & 0 & 0 & 0.6 \\
\hline pink granitic gneiss & Ygr & 2 & 2 & 0 & 0 & 1.1 \\
\hline \multicolumn{7}{|c|}{ Mafic rocks } \\
\hline amphibolite-bearing unit of Manhattan Schist & $\mathrm{Cma}$ & 3 & 3 & 0 & 0 & 0.4 \\
\hline Beardsley Member of Harrison Gneiss & $\mathrm{Ohb}$ & 9 & 8 & 0 & 0 & 0.5 \\
\hline Brookfield Gneiss & $\mathrm{Ob}$ & 14 & 12 & 0 & 0 & 1.2 \\
\hline dioritic phase of Lebanon Gabbro & Dld & 1 & 1 & 0 & 0 & $<0.2$ \\
\hline gneiss (metavolcanic) member of Brimfield Schist & Obrg & 5 & 5 & 0 & 0 & 0.3 \\
\hline Harrison Gneiss & $\mathrm{Oh}$ & 3 & 3 & 0 & 33.3 & 0.9 \\
\hline
\end{tabular}


Table 3. Arsenic and uranium concentrations that exceed maximum contaminant levels from 674 private wells in Connecticut, by geologic unit and major bedrock category, 2013-15.-Continued.

[Geologic unit names are the Connecticut Department of Energy and Environmental Protection preferred names as modified from Rodgers (1985). Bedrock categories (subheadings) are modified from Robinson and Kapo (2003). Color shadings indicate the percentage of wells with exceedances above concentration thresholds in ranges of , no data $(-)$; , less than $(<) 1$ percent; $\square, 1$ to 10 percent; $\square$, more than $(>) 10$ to 20 percent; $\square,>20$ to 30 percent; and $\square$, >30 percent. MCL, U.S. Environmental Protection Agency maximum contaminant level enforceable for public water supplies; $\mu \mathrm{g} / \mathrm{L}$, microgram per liter; NA, not available]

\begin{tabular}{|c|c|c|c|c|c|c|}
\hline \multirow[t]{2}{*}{ Geologic unit name } & \multirow[t]{2}{*}{$\begin{array}{l}\text { Geologic } \\
\text { unit code }\end{array}$} & \multicolumn{2}{|c|}{ Number of samples } & \multicolumn{2}{|c|}{$\begin{array}{l}\text { MCL, percentage }{ }^{1} \text { of } \\
\text { water samples with } \\
\text { concentrations, in } \\
\text { micrograms per liter }\end{array}$} & \multirow{2}{*}{$\begin{array}{c}\text { Percentage } \\
\text { of study area } \\
\text { underlain } \\
\text { by geologic } \\
\text { unit }^{2}\end{array}$} \\
\hline & & Arsenic & Uranium & $\begin{array}{l}\text { Arsenic } \\
>10 \mu \mathrm{g} / \mathrm{L}\end{array}$ & $\begin{array}{l}\text { Uranium } \\
>30 \mu \mathrm{g} / \mathrm{L}\end{array}$ & \\
\hline
\end{tabular}

\begin{tabular}{|c|c|c|c|c|c|c|}
\hline \multicolumn{7}{|c|}{ Mafic rocks-Continued } \\
\hline hornblende gneiss member of Collinsville Formation & Ocg & 3 & 3 & 0 & 0 & 0.4 \\
\hline Lebanon Gabbro & D1 & 2 & 2 & 0 & 0 & 0.3 \\
\hline massive mafic rock in Middletown Formation & Omm & 1 & 1 & 0 & 0 & $<0.2$ \\
\hline Pumpkin Ground Member of Harrison Gneiss & Ohp & 4 & 4 & 0 & 0 & 0.4 \\
\hline Quinebaug Formation & $\mathrm{Oq}$ & 11 & 5 & 0 & 0 & 1.8 \\
\hline \multicolumn{7}{|c|}{ Mesozoic basin sediments } \\
\hline East Berlin Formation & Jeb & 5 & 4 & 0 & 0 & 1.2 \\
\hline Hampden Basalt & Jha & 1 & 1 & 0 & 0 & 0.3 \\
\hline New Haven Arkose & TRnh & 20 & 20 & 0 & 0 & 5.7 \\
\hline Portland Arkose & $\mathrm{Jp}$ & 43 & 41 & 4.7 & 0 & 7.3 \\
\hline Shuttle Meadow Formation & Jsm & 1 & 1 & 0 & 0 & 0.4 \\
\hline
\end{tabular}

\begin{tabular}{|c|c|c|c|c|c|c|}
\hline \multicolumn{7}{|c|}{ Metamorphic rocks, other } \\
\hline Bristol Gneiss & Obs & 2 & 2 & 0 & 0 & 0.4 \\
\hline Clough Quartzite & $\mathrm{Sbc}$ & 1 & 1 & 0 & 0 & $<0.2$ \\
\hline Dalton Formation & $\mathrm{Cd}$ & 3 & 3 & 0 & 33.3 & 0.7 \\
\hline Fitch Formation & Sbf & 1 & 1 & 0 & 0 & $<0.2$ \\
\hline hornblende gneiss and amphibolite & Ygh & 1 & 1 & 0 & 0 & 0.7 \\
\hline Llayered gneiss & Ygn & 3 & 3 & 0 & 0 & 1.7 \\
\hline quartzite unit in Plainfield Formation & $\mathrm{Zpq}$ & 1 & 1 & 0 & 0 & 0.6 \\
\hline Tatnic Hill Formation & Ota & 22 & 20 & 0 & 5.0 & 2.8 \\
\hline \multicolumn{7}{|c|}{ Pelitic rocks } \\
\hline amphibolite unit in Ratlum Mountain Schist & Ora & 1 & 1 & 0 & 0 & $<0.2$ \\
\hline $\begin{array}{l}\text { basal member of Taine Mountain Formation around Waterbury } \\
\text { dome }\end{array}$ & Otb & 2 & 2 & 0 & 0 & 0.4 \\
\hline Collins Hill Formation & Och & 4 & 4 & 0 & 0 & 0.8 \\
\hline Collinsville Formation & Oc & 20 & 20 & 0 & 0 & 1.0 \\
\hline Golden Hill Schist & Ogh & 3 & 3 & 0 & 0 & 0.3 \\
\hline Hoosac Schist & $\mathrm{Ch}$ & 10 & 10 & 0 & 10.0 & 1.0 \\
\hline Littleton Formation & Dbl & 2 & 2 & 0 & 0 & 0.4 \\
\hline Manhattan Schist & $\mathrm{Cm}$ & 5 & 5 & 0 & 0 & 1.8 \\
\hline Maromas Granite Gneiss & $\mathrm{Dm}$ & 1 & 1 & 0 & 0 & $<0.2$ \\
\hline Oronoque Schist & Oo & 1 & 1 & 0 & 0 & 0.4 \\
\hline Ratlum Mountain Schist & Or & 47 & 40 & 0 & 2.5 & 4.0 \\
\hline Rowe Schist & $\mathrm{OCr}$ & 14 & 14 & 0 & 0 & 1.7 \\
\hline schist and granulite member of Trap Falls Formation & Otfg & 17 & 14 & 0 & 0 & 0.5 \\
\hline Scotland Schist & DSs & 3 & 3 & 0 & 0 & 0.9 \\
\hline Shelton (white gneiss) Member of Trap Falls Formation & Otfs & 3 & 3 & 0 & 0 & 0.3 \\
\hline Southington Mountain Member of The Straits Schist & DSts & 1 & 1 & 0 & 0 & 0.3 \\
\hline Taine Mountain Formation & $\mathrm{Ot}$ & 9 & 9 & 0 & 0 & 0.8 \\
\hline Taine Mountain Formation and Collinsville Formation undivided & $\mathrm{Ot}+\mathrm{Oc}$ & 4 & 4 & 25.0 & 25.0 & 0.3 \\
\hline The Straits Schist & DSt & 12 & 12 & 8.3 & 0 & 1.9 \\
\hline Walloomsac Schist & Ow & 6 & 6 & 0 & 0 & 0.5 \\
\hline Wepawaug Schist & DSw & 9 & 8 & 11.1 & 0 & 0.7 \\
\hline Whigville Member of Taine Mountain Formation & Otwv & 1 & 1 & 0 & 0 & $<0.2$ \\
\hline
\end{tabular}


Table 3. Arsenic and uranium concentrations that exceed maximum contaminant levels from 674 private wells in Connecticut, by geologic unit and major bedrock category, 2013-15.-Continued.

[Geologic unit names are the Connecticut Department of Energy and Environmental Protection preferred names as modified from Rodgers (1985). Bedrock categories (subheadings) are modified from Robinson and Kapo (2003). Color shadings indicate the percentage of wells with exceedances above concentration thresholds in ranges of , no data $(-)$; , less than $(<) 1$ percent; $\square, 1$ to 10 percent; $\square$, more than $(>) 10$ to 20 percent; $\square,>20$ to 30 percent; and $\square$, >30 percent. MCL, U.S. Environmental Protection Agency maximum contaminant level enforceable for public water supplies; $\mu \mathrm{g} / \mathrm{L}$, microgram per liter; NA, not available]

\begin{tabular}{|c|c|c|c|c|c|c|}
\hline \multirow[t]{2}{*}{ Geologic unit name } & \multirow[t]{2}{*}{$\begin{array}{l}\text { Geologic } \\
\text { unit code }\end{array}$} & \multicolumn{2}{|c|}{ Number of samples } & \multicolumn{2}{|c|}{$\begin{array}{l}\text { MCL, percentage }{ }^{1} \text { of } \\
\text { water samples with } \\
\text { concentrations, in } \\
\text { micrograms per liter }\end{array}$} & \multirow{2}{*}{$\begin{array}{c}\text { Percentage } \\
\text { of study are } \\
\text { underlain } \\
\text { by geologic } \\
\text { unit }^{2}\end{array}$} \\
\hline & & Arsenic & Uranium & $\begin{array}{l}\text { Arsenic } \\
>10 \mu \mathrm{g} / \mathrm{L}\end{array}$ & $\begin{array}{l}\text { Uranium } \\
>30 \mu \mathrm{g} / \mathrm{L}\end{array}$ & \\
\hline \multicolumn{7}{|c|}{ Sulfidic schists } \\
\hline Brimfield Schist & Obr & 33 & 32 & 0 & 0 & 3.2 \\
\hline Carringtons Pond Member of Trap Falls Formation & Otfc & 3 & 3 & 33.3 & 0 & 0.5 \\
\hline rusty mica schist and gneiss & Ygs & 2 & 2 & 0 & 0 & 0.9 \\
\hline upper slice of Canaan Mountain Schist & Cmcu & 1 & 1 & 0 & 0 & 0.3 \\
\hline unmapped areas & NA & 1 & 1 & 0 & 0 & 1.0 \\
\hline Overall for the study area & NA & 660 & 589 & 3.6 & 3.9 & 82.4 \\
\hline
\end{tabular}

${ }^{1}$ The percentage (of exceedance) values for geologic units computed for this study may not represent the actual risk for existing and future wells in these units.

${ }^{2}$ About 17.6 percent of the study area (State of Connecticut) was underlain by 75 individual geologic units from which no water samples were collected.

to which these geologic units are within its borders. This is demonstrated by examining all available water-quality data for three towns with the largest number of sampled wells (table 4). In Stamford, which is in southwestern Connecticut (fig. 2), 0.1 percent of 732 samples had high arsenic concentrations $(>10 \mu \mathrm{g} / \mathrm{L})$ and 11.2 percent of 731 samples had high uranium concentrations ( $>30 \mu \mathrm{g} / \mathrm{L}$; table 4$)$. This difference in occurrence rates between the two elements is likely explained by the geologic setting of the town. Much of Stamford is underlain by the Harrison Gneiss geologic unit of the Mafic rocks bedrock category and the Trap Falls Formation and Ordovician granitic gneiss undivided geologic unit of the Granite, other bedrock category. For these two units, none of the samples in

Table 4. Arsenic and uranium concentrations that exceed maximum contaminant levels from private wells in Connecticut, for three towns, 2013-15.

[MCL, U.S. Environmental Protection Agency maximum contaminant levels enforceable for public water supplies; $\mu \mathrm{g} / \mathrm{L}$, microgram per liter; > greater than; - , no data]

\begin{tabular}{|c|c|c|c|c|}
\hline \multirow{2}{*}{ Town } & \multicolumn{2}{|c|}{ Number of samples } & \multicolumn{2}{|c|}{$\begin{array}{c}\text { Percentage of samples with } \\
\text { concentrations that exceed } \\
\text { MCL }\end{array}$} \\
\hline & Arsenic & Uranium & $\begin{array}{l}\text { Arsenic } \\
>10 \mu \mathrm{g} / \mathrm{L}\end{array}$ & $\begin{array}{l}\text { Uranium } \\
>30 \mu \mathrm{g} / \mathrm{L}\end{array}$ \\
\hline Stamford & 732 & 731 & 0.1 & 11.2 \\
\hline Weston & 110 & - & 47.3 & - \\
\hline Wilton & 81 & 80 & 2.5 & 7.5 \\
\hline $\begin{array}{r}\text { Statewide } \\
\text { dataset }\end{array}$ & 660 & 589 & 3.6 & 3.9 \\
\hline
\end{tabular}

the statewide dataset had high arsenic concentrations, yet 33.3 and 11.1 percent, respectively, of samples had high uranium concentrations (table 3).

The towns of Weston and Wilton are adjacent to each other in southwestern Connecticut (figs. 1 and 2). However, more than 47 percent of samples in Weston had high arsenic concentrations, but only 2.5 percent of samples in Wilton had high arsenic concentrations (table 4). In Weston, the dominant geologic unit is the Ordovician granitic gneiss of the Granite, other bedrock category, and 14.3 percent of 56 samples from this unit in the statewide dataset had high arsenic concentrations (table 3). In Wilton, the dominant geologic units are the Harrison Gneiss and the Pumpkin Ground Member of Harrison Gneiss (Mafic rocks bedrock category), and the Trap Falls Formation and Ordovician granitic gneiss undivided of the Granite, other bedrock category; none of the wells from these units in the statewide dataset had high arsenic concentrations (table 3).

\section{Human Health Implications}

High concentrations of arsenic and uranium in drinking water have been associated with increased risk of lung, bladder, and skin cancers for arsenic and adverse effects on kidney function for uranium (Magdo and others, 2007). For households in Connecticut that rely on private wells for drinking water, this study has shown that the likelihood of having arsenic or uranium concentrations that exceed human-health benchmarks may depend in large part on the particular geologic unit in which the household's well is located. Other factors can affect arsenic or uranium concentrations, such as geochemical conditions or residence time for water-rock reactions in the local groundwater system. For more information about well testing and treatment guidelines in Connecticut (Connecticut Department of Public Health, 2013), contact the Connecticut Department of Public Health Private Well Program by calling (860) 509-7296 or visit their website at http://www.ct.gov/dph/privatewells. 


\section{Acknowledgments}

This study was prepared in cooperation with the DPH as part of their cooperative agreement with the National Center for Environment Health of the Centers for Disease Control and Prevention of the U.S. Department of Health and Human Services to provide support for public health drinking water programs to reduce drinking water exposures. The authors thank Laura Apinis and Jack Bennett at the DPH Laboratory for sample analysis; Brian Toal, Gary Archambault, Sharee Rusnak, Kenny Foscue, Ryan Tetreault, and Tiziana Shea at the DPH for the trace-element and site location data used in this study; and Connecticut State Geologist Margaret Thomas for her input.

\section{References Cited}

Ayotte, J.D., Montgomery, D.L., Flanagan, S.M., and Robinson, K.W., 2003, Arsenic in groundwater in eastern New England: occurrence, controls, and human health implications: Environmental Science and Technology, v. 37, no. 10, p. 20752083. [Also available at https://nh.water.usgs.gov/ Publications/2003/es026211g.pdf.]

Ayotte, J.D., Nolan, B.T., Nuckols, J.R., Cantor, K.P., Robinson, G.R., Jr., Baris, Dalsu, Hayes, Laura, Karagas, Margaret, Bress, William, Silverman, D.T., and Lubin, J.H., 2006, Modeling the probability of arsenic in groundwater in New England as a tool for exposure assessment: Environmental Science and Technology, v. 40, p. 3578-3585.

Colman, J.A., 2011, Arsenic and uranium in water from private wells completed in bedrock of east-central MassachusettsConcentrations, correlations with bedrock units, and estimated probability maps: U.S. Geological Survey Scientific Investigations Report 2011-5013, 113 p.

Connecticut Department of Public Health, 2013, Private well testing: Connecticut Department of Public Health Publication no. 24, 6 p. [Also available at http://www.ct.gov/dph/lib/dph/ environmental_health/eoha/pdf/24_residential_drinking water_well_testing.pdf.]

Connecticut Department of Public Health, 2016, Private wells: Connecticut Department of Public Health Web page, accessed March 29, 2016, at http://www.ct.gov/dph/cwp/view. asp? $\mathrm{a}=3140 \& \mathrm{q}=400544$.

Flanagan, S.M, Belaval, Marcel, and Ayotte, J.D., 2014, Arsenic, iron, lead, manganese, and uranium concentrations in private bedrock wells in southeastern New Hampshire, 2012-2013: U.S. Geological Survey Fact Sheet 2014-3042, 6 p., appendixes. [Also available at https://doi.org/10.3133/ fs20143042.]

Flanagan, S.M., and Brown, C.J., 2017, Inventory of waterquality and geologic-setting data from 674 private wells in Connecticut, 2013-2015: U.S. Geological Survey data release, https://doi.org/10.5066/F7K935P5.
Magdo, S.H., Forman, Joel, Graber, Nathan, Newman, Brooke, Klein, Kathryn, Satlin, Lisa, Amler, R.W., Winston, J.A., and Landrigan, P.J., 2007, Grand rounds-Nephrotoxicity in a young child exposed to uranium from contaminated well water: Environmental Health Perspectives, v. 115, no. 8, p. 1237-1241.

Montgomery, D.L., Ayotte, J.D., Carroll, P.R., and Hamlin, Patricia, 2003, Arsenic concentrations in private bedrock wells in southeastern New Hampshire: U.S. Geological Survey Fact Sheet 03-051, 6 p. [Also available at https://pubs.er.usgs.gov/publication/fs05103.]

Robinson, G.R., Jr., and Ayotte, J.D., 2006, The influence of geology and land use on arsenic in stream sediments and ground waters in New England, USA: Applied Geochemistry, v. 21, p. $1482-1497$.

Robinson, G.R., Jr., and Kapo, K.E., 2003, Generalized lithology and lithogeochemical character of near-surface bedrock in the New England region: U.S. Geological Survey Open-File Report 03-225, 60 p. [Also available at https://pubs.er.usgs.gov/publication/ofr03225.]

Rodgers, John, comp., 1985, Bedrock geological map of Connecticut: Connecticut Geological and Natural History Survey, Natural Resource Atlas Map Series, scale 1:125,000, 2 sheets, accessed December 12, 2016, at https://ngmdb.usgs.gov/ Prodesc/proddesc_54245.htm.

U.S. Environmental Protection Agency, 1994, Methods for the determination of metals in environmental samples, supplement I (rev. 5.4): U.S. Environmental Protection Agency EPA/600/R-94/111, 260 p.

U.S. Geological Survey, 2016, The Branch of Quality Systems: accessed November 2016, at https://bqs.usgs.gov.

\section{For additional information, contact}

Director, New England Water Science Center

U.S. Geological Survey

331 Commerce Way, Suite 2

Pembroke, NH 03275

Telephone: (603) 226-7800

Email: dc_nh@usgs.gov

Or visit our website at

https://newengland.water.usgs.gov/

By Sarah M. Flanagan and Craig J. Brown 